This is a pre-copyedited, author-produced version of an article accepted for publication in International Studies Quarterly following peer review. The version of record Joseph MacKay, Christopher David LaRoche, Why Is There No Reactionary International Theory?, International Studies Quarterly, Volume 62, Issue 2, June 2018, Pages 234-244, https://doi.org/10.1093/isq/ sqx083 https://academic.oup.com/journals/pages/access_purchase/rights_and_permissions/self_archiving_policy_f (Publisher journal website 15/5/2019)

\title{
Why Is There No Reactionary International Theory?
}

\author{
Authors: \\ Joseph MacKay (joseph.mackay@utoronto.ca) \\ Postdoctoral Research Fellow \\ Harriman Institute \\ Columbia University \\ Christopher David LaRoche \\ Doctoral Candidate \\ Political Science \\ University of Toronto
}

\begin{abstract}
:
Why is there no reactionary international theory? International Relations has long drawn on a range of traditions in political thought. However, no current or recent major IRtheoretic school is expressly reactionary. This is surprising both because reaction was once common in IR, and is now common in world politics. We define reaction as a form of political nostalgia: a belief the past was better than the present and likely future, generally accompanied by a desire to recover that prior condition. The current lack of reactionary IR impacts the field's capacity to make sense both of its own history and of reactionary practice in the world. In this exploratory account, we provide a definition of reaction, then show no current school of IR theory falls within it - but that it nonetheless once deeply shaped the field. We survey reactionary ideas in the history of political thought, finding a cogent and persistent tradition. We then explore the impact of reactionary ideas on the practice of world politics, identifying two distinct varieties of reactionary state and illustrating them empirically. We conclude by considering the question of why reaction is now absent from IR theory-yet all around us in world politics.
\end{abstract}

Word Count: 10,000

Acknowledgements: The authors would like to thank Kiran Banerjee, Scott Dodds, Alena Drieschova, Michael Millerman, and David Polansky, who (along with considered disagreements) offered a range of helpful comments. 


\section{Introduction}

Why is there no reactionary international theory? ${ }^{1}$ Contemporary International Relations (IR) scholarship draws on multiple intellectual traditions, from liberal, to status-quo realist, to radical and critical positions. However, we argue, the discipline has no expressly reactionary school — one that rejects the present in favour of the past. The systematic and sometimes radical nostalgia of reactionary politics, distinct from liberalism or realism, is almost entirely absent from the contemporary field. This absence is striking because reaction itself has a long history in political thought and practice. Indeed, as recent historiography of the field implies, reaction was part of IR at its inception. ${ }^{2}$ We call on IR scholars to re-examine reactionary politics - both in the discipline and in history more broadly — and thereby better understand and address these persistent and consequential phenomena.

We write not as reactionaries ourselves, but as concerned members of the discipline. We do not claim expressly reactionary IR theory is necessary to understand reactionary world politics. Instead, we contend the absence of reactionary theory has likely shaped the field's inattention to political reaction as such. While political reaction may be overlooked in current IR theory, it is all around us in contemporary politics. We see it in western nativist movements that, reacting to globalism, defend once "purer," racially or culturally homogenous societies and call for closed borders; and in the Islamist radicalism those nativists condemn, itself recalling an idealized Pax Islamica of more than a millennium ago. These ideas shape world politics, and share a common attitude toward historical change - yet current IR has scant systematic understanding of them.

By reactionary, we mean a specific political attitude toward long-run historical change. The word has more commonly been used as term of abuse than one of selfattribution - a pejorative description for all and only those who unthinkingly reject the fruits of progress. In contrast, we find a potentially systematic, influential, and important

\footnotetext{
${ }^{1}$ We allude to Wight (1966), whose own political orientation we review below.

2 That research challenges IR's once-canonical origin story as a battle between liberal progressives and their realist critics, pointing to more heterodox and sometimes problematic beginnings (Schmidt 2012; Guilhot 2013; Vitalis 2015). While some assesses expressly conservative international thought (Hall and Rengger 2005; Hall 2015), little treats reaction rigorously and specifically as an analytical category.
} 
tradition, predicated on a distinctive attitude toward history. Liberal progressives and radicals alike view much historical change, expressly or tacitly, as both possible and morally good or desirable. Realists emphasize what they see as fundamental, recurring elements of international order over change. In contrast, reactionaries neither embrace historical change nor reject the possibility of it. Instead, they understand deep historical transformations as both real and catastrophic. For reactionaries, the world was once better: a past political order, now lost, shows us retrospectively how politics should be ordered, but no longer is. Fixated on this prelapsarian world, reaction is a doctrine of political nostalgia, imagining a past it hopes to recreate. ${ }^{3}$

We offer an exploratory account of reactionary international politics, proceeding in four sections. First, we define political reaction. Second, we show its near-complete absence from contemporary IR-theoretic schools. We also explore the field's reactionary early history, and find scattered and incomplete reaction in more recent IR. Third, for context, we offer a brief history of western reactionary political thought. Fourth, we illustrate its importance in world politics, identifying two reactionary strategies in world politics_-revisionism and restructuring — with respective historical examples: Nazi Germany and the Concert of Europe's counter-revolutionary "Metternich system.” A conclusion rethinks reaction's place in the field.

\section{What is political reaction?}

We understand reaction as the claim that a past political order is preferable to the present, often accompanied by attempts to restore that past order. ${ }^{4}$ Like liberal progressivism or Marxian radicalism, reaction is an attitude toward processes, chiefly

\footnotetext{
${ }^{3}$ On how theories or philosophies of history shape IR, see MacKay and LaRoche (2017).

${ }^{4}$ We draw here on Lilla's (2016) recent concise theoretical work. So defined, reaction is distinct from such related concepts as conservatism, nostalgia, romanticism, populism, nationalism, and others. We thus adopt a more specific definition than Robin (2011:34), who uses "the words conservative, reactionary, and counterrevolutionary interchangeably" - treating conservative "philosophers, statesmen, slaveholders, scribblers, Catholics, fascists, evangelicals, businessmen, racists, and hacks" as belonging to the same core political experience: "a meditation on — and theoretical rendition of - the felt experience of having power, seeing it threatened, and trying to win it back" (Robin 2011:4, see also 28). Such elite impulses may animate reaction as we define it, but need not. Nor, we argue below, need reaction be strictly rightwing. Eliding distinctions between these terms makes for less precise and useful analysis.
} 
modern, of historical transformation. Its distinguishing feature is a belief that reformist or progressive change is fundamentally destructive. However, where progressives imagine a better world that does not yet exist, reactionaries refer to one they understand as already behind us. ${ }^{5}$ Reactionary politics have often historically been as convincing to audiences as these other traditions. As Lilla (2016:xiv) notes, "Hope can be disappointed. Nostalgia is irrefutable". 6

We define reaction in terms of three basic features: a belief in a lost prior order constitutive of the good life or conditions for human flourishing, recognition of a specific event or process that destroyed it, and an account of who or what is to blame for that destructive change. A reactionary international politics is a doctrine that imagines a past either in which a given national political order (now lost) was secure within the larger world order, or in which world order itself was both different and preferable. ${ }^{7}$ Common in political thought, reaction has repeatedly informed practical politics. These stipulations constitute an ideal type - an analytically simplified account that, while precisely describing few cases, nonetheless captures core features held in common across most instances. ${ }^{8}$ We take them briefly in turn.

First, reaction imagines a past preferable to the present or expected future. It posits a long-run historical trajectory, over which change is linear and systematically knowable. Thus, religious radicalisms, nativisms, and others alike begin by describing an idealized past baseline condition. This history need not be complete or even accurate. Catholic reactionaries may excoriate the Reformation as dogmatic, blaming it for later events such as the French Revolution, but also deemphasize Medieval Christendom's less attractive doctrinal practices, such as the Inquisition. ${ }^{9}$ Violent reactionaries in the west

\footnotetext{
${ }^{5}$ Bauman $(2017: 5,8)$ terms this imagined past "retrotopia."

${ }^{6}$ The word was coined in 1688, by a Swiss medical student, from the Greek nostos (return or homecoming) and algos (pain). It originally described a psychiatric diagnosis: a malignant and destructive homesickness, and more broadly to a "refusal to consider any but a world lost to the past as the habitable world" (Roth 1991:15). It is linked to longing for one's homeland, and thus to nationalism.

${ }^{7}$ Thus, for example, the "fascist internationalism" of the interwar period (Steffek 2015:3-4).

${ }^{8}$ On ideal-typification in IR, see Jackson (2011:37, 142-46).

${ }^{9}$ See for example Kuehnelt-Leddihn (1952:179-187); Gregory (2012) more recently locates modern disillusionment in the Reformation.
} 
today, such as Theodore Kaczynski or Anders Breivik, imagine technologically or racially different pasts, with dubious historical accuracy. Islamic radicals likewise may be largely silent on the violence, slavery, and eventual corruption of the early Caliphates. Instead, the putative status quo ante represents a condition of greater moral-political wellbeing than the present. These emphases may be intentional, treating these trade-offs as justified. In some instances, reactionaries may simply mythologize the past. Regardless, these beliefs about history structure reactionaries' general political stance. Second, reactionaries imagine an event or process that destroyed that order. Reactionaries understand "progressive" political change as destructive, whether by cataclysm or gradual decay. For nineteenth century reactionaries, this signal event was the French Revolution, understood as the product of the Enlightenment's disenchantment of tradition religious authority (Maistre 1994). Late twentieth century American reactionaries often blamed societal instability on "social engineers" disrupting traditional ways of life (Buckley 1955). To treat the past as prelapsarian, reactionaries must identify the Fall by which it was destroyed.

Third, to explain this destructive change, some actor or group must be understood to have caused it. They may have done so by undermining a delicate socioeconomic compact, by questioning assumptions long sacred to the social order, or by otherwise disrupting political life. Islamic radicals have often blamed European imperialism, and Islamic attempts at modernization in response, for the nineteenth and twentieth century moral and political nadir of the Islamic world (Euben 1999:93-94). The Nazis blamed the Jews for the decadence, moral disorder, international capitalism, and destruction of national culture they claimed to see in modern Europe. As these examples suggest, this component may have some basis in fact or none at all. Nor need the disruption be intentional. Intellectual anti-moderns need not claim Enlightenment philosophers meant to destroy medieval European civilization — disillusionment was merely a by-product of their intellectual flourishing.

With this definition in mind, some qualifications are in order. First, as we note above, this account of political reaction is ideal-typical, describing a simplified, idealized form of reactionary belief. Cases may fit imperfectly, and some will be borderline. Degrees of reaction will vary, both in the remoteness of the past recalled and the means 
mobilized to recapture it. Where Metternich wanted only to restore a pre-revolutionary monarchical Europe, Hitler aimed to recover an imagined pre-modern utopia. What matters is not our ability to neatly and unproblematically categorize theorists, movements, and regimes. Instead, we aim to chart reaction, by degrees, across cases and contexts.

Second, while we focus on conservative reactionaries, reaction is not coextensive with the political right (Lilla 2016:xii). The British luddites were workers who recalled a past in which their labour had not yet been replaced by machines (Randall 1986:8-9). Some deep ecologists today imagine restoring a closer, preindustrial link between humanity and nature (Devall and Sessions 1985). Contemporary opponents of modern medicine (e.g., vaccine sceptics) sometimes idealize, tacitly or explicitly, a more natural human past, reliant on folk remedies instead of modern pharmacology (e.g., Kata 2010:171-14). Inversely, many conservatives have scant reactionary beliefs. Burke (2014) grounded his impassioned criticism of the French Revolution in a defence of gradual and local change, not of wholesale return to the past. More recent free market conservatives or libertarians need not be explicitly nostalgic at all (Friedman 1962:721). ${ }^{10}$

Third, we focus on reaction primarily as a modern and western phenomenon. Accelerated change linked to intellectual, political, and industrial modernity, perhaps first and most acutely in the west, provide conditions in which reactionary thinking has become commonplace. Elsewhere, modernity often occurred first as colonial domination. Responses to it were consequently different, and varied widely across contexts. ${ }^{11}$ In principle, political reaction may be a non-modern phenomenon-Confucius and Homer both recalled golden ages prior to their own. Nor is all criticism of modernity reactionary. Those who link declining attention spans to social media, or question the uneven effects of globalization on traditional ways of life, are not necessarily reactionary. Reactionaries

\footnotetext{
${ }^{10}$ Nor is reaction equivalent to populism, which may be a doctrine of the left or right, and says nothing systematic about the past (Müller 2016). Nor is reaction inherently populist — it may be a doctrine of return to traditional social hierarchy.

${ }^{11}$ Such reaction contrasts with more common progressive or radical anti-colonialism (e.g., Fanon 1965). Elsewhere, quasi-modernities may have emerged independently of the west (Woodside 2009).
} 
go beyond criticism to idealize a past social order, endorsing it over the present. Criticism aims to understand modernity; reaction sets out to replace it. ${ }^{12}$ Nonetheless, modernity presents distinctive conditions of persistent transformation, which have permitted antimodern nostalgia to proliferate (Lilla 2016:xiv).

\section{Reactionary International Relations}

With this definition, we are positioned to see that no major contemporary schools in IR theory are meaningfully reactionary. This should be obvious as regards the progressivism of liberals (classical or neo-) and radicalism of historical materialists. ${ }^{13}$ Canonical forms of these IR-theoretic schools all imagined better futures that differ from the past, whether as products of gradual evolution or revolutionary struggle. ${ }^{14}$ However, schools sometimes called conservative also tend not to be reactionary, at least in more recent formulations. Realism, the school most commonly linked to conservatism, describes no corrosive historical change, instead questioning whether fundamental international change is possible at all. Here, Waltz (1979:66) is perhaps clearest: "The texture of international politics remains highly constant, patterns recur, and events repeat themselves endlessly. The relations that prevail internationally seldom shift rapidly in type or in quality. They are marked instead by dismaying persistence." Mearsheimer's (2003:2) more recent assessment is similar: "international politics has always been a ruthless and dangerous business, and it is likely to remain that way.... [G]reat powers fear each other and always compete with each other for power." There is little transformation of any kind in this vision— good or ill.

Many classical realists had some reactionary sentiments, though none amount to a wholly reactionary theory. Morgenthau, Kennan, and Kissinger all expressed nostalgia for a nineteenth century diplomatic order that predated the democratization of foreign

\footnotetext{
${ }^{12}$ Similarly, not all theoretical criticism of modernity proposes a reactionary political program (e.g., Leo Strauss). Other schools, such as postmodernism, are hostile to modernity without nostalgia of any kind. Some theoretical critics of modernity may even aim to ameliorate modern political practice (e.g., Hannah Arendt). See note 37, for two liminal cases, Martin Heidegger and Carl Schmitt.

${ }^{13}$ IR scholars tend to have left-liberal political views (Maliniak, Peterson, and Tierney 2012).

${ }^{14}$ Early IR liberal idealists were progressive, and sometimes anti-imperialist, as was Angell, but also paternalistic and Eurocentric - and thus at least potentially reactionary (Hobson 2012:40-45). On Angell generally, see Ceadel (2009).
} 
policy. ${ }^{15}$ But Morgenthau, like Niebuhr, emphasized the unchanging "perennial” political problems that impede progress and prevent any set of social norms from solving thempast or present. ${ }^{16}$ Kennan's views on social hierarchy and race led him to condemn South African apartheid while discouraging American efforts to end it. ${ }^{17}$ Recent scholarship furthermore finds critical, liberal, or progressive elements in many classical realists, including Morgenthau, Niebuhr, Carr, Wolfers, and Herz (Williams 2005a:82-127; Neacsu 2010; Scheuerman 2011; Levine 2012:120-135). ${ }^{18}$ Raymond Aron's defense of liberalism is well known, ${ }^{19}$ while Kissinger's work has shifted over time to cautiously embrace elements of progressive liberal internationalism. ${ }^{20}$ Whatever their differences, then, classical and neo-realists alike view historical transformation as not destructive, so much as fundamentally impossible or misguided, at least on the terms of their liberal antagonists. ${ }^{21}$ So understood, realist values are not strictly reactionary.

Another possible site of reactionary IR theory is the English School, sometimes identified as conservative (Buzan 2014:89 passim). Much of this conservatism is either broadly Burkean or gradualist, or is the status-quo conservatism of realism. However, as

${ }^{15}$; See the review in Bessner and Guilhot (2015:85-98); for Morgenthau specifically see Neacsu (2010:chaps. 4 \& 5).

${ }^{16}$ See Morgenthau (1948:13, 2004:15-16) and Niebuhr (2008:chap. 7). While both differ from Waltzian structuralism, their stances on history assert that violence is persistent and international progress tenuous at best.

${ }^{17}$ See Gaddis (2011:603-605), who notes that Kennan “long believed that race shaped culture.” Kennan's (2014:46-47) diaries suggest a generalized nostalgia: "I cannot help but regret I did not live fifty or a hundred years sooner.... I should have lived in those days when... foreign countries were still foreign, when a vast part of the world always bore the glamour of the great unknown, when there were still wars worth fighting and gods worth worshipping."

18 The later Morgenthau, for example, endorsed world federalism (Scheuerman 2011:117-158).

${ }^{19}$ For an overview, see Anderson (1997).

${ }^{20}$ See Kissinger (1994:804-812, 832-836, 2014:371-374, 372): “A world order of states affirming individual dignity and participatory governance, and cooperating internationally in accordance with agreedupon rules, can be our hope and should be our inspiration. But progress toward it will need to be sustained through intermediary stages." In his first book Kissinger (2013) expressed admiration for Metternich's post-Napoleonic restoration (see below).

${ }^{21}$ Carr (2001:113) had an exceptional, quasi-Hegelian view of progress, seeing it as possible but aimed toward goals revealed only as they were realized (MacKay and LaRoche 2017:24). 
Hall (2011:48-55) has shown, many first generation English School scholars, including Butterfield and Wight, were prone to often strident imperial nostalgia. This affirmative recollection of imperialism was often tied up with nostalgia for imperial-era international society. Early English School theorists recalled this period as more socially "thick" and more pacific, thus linking colonial notions of hierarchy and civilizational superiority to a stable and peaceful international order. Hedley Bull was relatively isolated among them in finding decolonization politically acceptable. ${ }^{22}$ However, second generation English School accounts locate any such tendencies within the school's larger pluralist framework (Little 2000; Buzan 2004). Third generation English School work can be more or less explicitly anticolonial (Suzuki 2009).

Other exceptions are rare and are mostly partial, thus tending to prove the rule. While power transition theories generally view rising powers as more risk acceptant than declining ones (Gilpin 1983), some formulations emphasize the willingness of declining states to accept increasing risks (Levy 1987). Here though, the motivation is to prevent later and more destructive wars, not to recover lost power and standing. Schweller (2014) describes an entropic process by which the increasingly complex modern world becomes increasingly disordered and chaotic. However, he does not describe a specific Fall from a clearly delineated better past, nor does he hold anyone responsible - the effect is structural. Neoconservatives have deep ties to some forms of liberalism, and lack standard formulations in IR theory - the field tends to rely on outside analytical reconstructions (e.g., Williams 2005b).

Perhaps the most overtly reactionary IR-theoretic work in recent decades is Huntington's (1997) Clash of Civilizations. Huntington emphasizes group identity and fellow feeling, locating it in large, historically rooted silos - prone, he believed, to conflict with one another. Taken together with his subsequent account of American national identity (Huntington 2004), he explicitly linked civilizational conflict to a preference for ethnonationally homogenous states and culturally homogeneous civilizations - a narrative that implied a return to a previous, more culturally uniform social order at home, and antagonism abroad. The framework implies a narrative of decline, with homogeneity under attack by expanding liberal multiculturalism.

\footnotetext{
${ }^{22}$ See for example Bull (1959), discussion in Hall (2011:51-52).
} 
Distinguishing between Huntington's earlier and later work, Hassner $(1996: 65,69)$ usefully summarizes: while Huntington rejected framing his later argument in terms of modernization and Weberian disenchantment, his civilizational emphasis on "tradition and religion cannot be understood except as a reaction to modernization and its discontents". The rise of civilizational international politics makes sense only if construed as reactionary. As Welch (2013) notes, Huntington implied a normative endorsement: the account was neither predictive nor explanatory—instead, "it was a wish." However, despite recurring appearances in non-academic settings, IR remains consistently critical of Huntington's later work, suggesting he led no larger trend in the field. ${ }^{23}$

Importantly, a school of thought need not itself be normatively reactionary to provide analytical insights into reactionary politics. Absent a reactionary school, we might look for scholars who take reaction as an object of study. Constructivism, as the IR theory focused on ideas might in principle offer a way to take reaction seriously. In practice, however, the social construction of international reaction remains largely undocumented in IR. While some constructivist studies emphasize the divisive, realist, power-politics of ideas (Mitzen 2006; Barkin 2010), scant attention has been paid to ideas directly opposed to narratives of historical progress. Psychological accounts of identity emphasize in-group/out-group dynamics (Mercer 1995), but not over time. ${ }^{24}$ Postcolonial IR finds imperial nostalgia in contemporary world politics (e.g., Seth 2013), but does not offer a systematic treatment of reaction as such.

Strikingly, however, this absence itself elides a history of reactionary and quasireactionary tendencies in early IR. ${ }^{25}$ Many strands in the field's early history included forms of imperial, geopolitical, or racialized nostalgia. As Hobson (2012:chaps. 5 \& 7) has pointed out, early twentieth century classical geopolitics had pronounced reactionary strains, running from geographic ethnonationalism to imperial nostalgia. Halford

\footnotetext{
${ }^{23}$ Huntington's thesis has repeatedly been shown to be empirically wrong (Chiozza 2002; Fox 2002; survey in Musgrave 2017). His account is distinct from constructivist accounts of grand cultural or civilizational difference (e.g., Katzenstein 2009; Acharya 2014).

${ }^{24}$ Exceptionally, Freedman (2016) emphasizes lost perceived status, and attempts to regain it.

${ }^{25}$ Although reflexive IR scholars such as Hobson have recently (re)-connected classical geopolitics to early IR, this critique was first made by critical geographers vis-à-vis their own discipline: see Tuathail (1996); Tuathail, Dalby and Routledge (2006).
} 
Mackinder aimed much of his work, including his now-famous 'geographical pivot' theory, at renewing British seafaring imperialism against competition from land empires. In the United States, Alfred Mahan used geopolitical concepts to advocate American naval militarism (Tuathail 1996:chaps. 1, 3; Black 2016:126-141). Both were concerned with the "closing of the world" - the increasing proximity of once isolated societies, and particularly the challenge of an encroaching "Asiatic" world to the west (Hobson 2012:123-130). Reacting to Germany's post-1919 crises, German geographers also attempted to put geopolitical theories in service of revived German expansion. After World War 2, classical geopolitics was shunned as a formal academic discipline because of its associations with Nazism (Tuathail 1996:chap. 4; Black 2016:chap. 7; cf. Hobson 2012:158-165). When Kissinger and others revived the term "geopolitics" in the Cold War, their usages were stripped of theoretical content and deployed as "casual synonyms for realist views of international strategic rivalry and interaction" (Deudney 2000:79), thus eliding the concept's reactionary linkages. ${ }^{26}$

This history of reaction in early IR has become increasingly well documented. As Vitalis (2015) shows, early IR, including early liberalism, was deeply tied up with the linked tasks of imperial administration and the maintenance of white supremacy. ${ }^{27} \mathrm{As}$ European imperialism waned and collapsed, post-war British liberal imperialists in international studies became, in relative terms, tacit reactionaries: nostalgic adherents of an older order (Hall 2011:44-47). Most of this history was later concealed behind a

\footnotetext{
${ }^{26}$ Recent geopolitics revivals acknowledge critical geography's critique while disagreeing with its poststructuralism (e.g., Deudney 2000; Kelly 2016:45-69; Black 2016:202-204, 229-239).

${ }^{27}$ For example, Foreign Affairs was founded as the Journal of Race Development (Vitalis 2015:ix-x). The elision of such episodes from standard histories of the field is a double injustice, obscuring both IR's imperial origins and the early scholars who resisted it. Henderson (2017) documents the contributions of the "Howard School" (the term is Vitalis's) to IR theory. Some early American political scientists, such as Paul Reinsch, advocated a more "benign" imperialism (Schmidt 2008; Hobson 2012:121-123). This broader racialized history of the early field overlaps only partially with political reaction as we define it. Rather than being reactionary or nostalgic at the time, racism was all too normal.
} 
reconstructed history of "great debates," in which the discipline putatively emerged from dialogue between liberals and realists, with imperial nostalgia erased from the narrative. ${ }^{28}$

We conclude that contemporary IR is almost entirely without systematically reactionary thinkers. However, disciplinary IR thereby elides a significant portion of its own history. Indeed, that history is unexceptional: reaction has deeply shaped both modern political theory (in its many anti-modern forms), and modern world political practice. We address these in the next two sections.

\section{A Brief History of Political Reaction}

The formative event in modern political reaction was the French Revolution, out of which the term réaction was coined to refer to anyone who opposed the Jacobins (Lilla 2016:xi). Although some early modern thinkers protested large-scale change-Thomas More's campaign against the Reformation is exemplary - reactionary thought in the sense we mean emerged from the Revolutionary period. The canonical statement was Joseph de Maistre's (1994) Considérations sur la France, which advanced a providential, theocratic understanding of politics, blamed the revolution on the pernicious effects of Enlightenment philosophy, and advocated a Bourbon restoration. ${ }^{29}$ As Pierre Manent writes in his introduction to Maistre (2006:vii), "instead of critiquing the Revolution for this or that measure, or for its excesses in general, [Considérations] rejects it entirely, in its essence, as contrary to the very nature of social and moral man.” By defending hierarchical political tradition against what he saw as abstract and destructive Enlightenment political rationalism, Maistre helped establish and spread an intellectual tradition dedicated to the restoration and defence of a idealized past. ${ }^{30}$

\footnotetext{
${ }^{28}$ Indeed, tropes now thought of as typifying the period had roots in geopolitical forerunners. For example, Carr's utopian vs. realism formulation is prefigured by Mackinder's (1919:10-16) reference to "democratic idealism" and "reality." For Mackinder, however, reality and idealism can become synthetized in modernist efficiency, the excesses of which may be destructive- his diagnostic case is the French Revolution's Terror. The modern realist critique of idealism goes back at least to Machiavelli (Pangle and Ahrensdorf 1999:chaps. $4 \& 5$ ), but is distinct from reactionary politics as defined here.

${ }^{29}$ See Maistre (1994:62-76, 84-85; emphases original): "It will be in the name of the VERY GOOD AND VERY GREAT GOD... that you will return to your old constitution and that a king will give you the only thing that you ought wisely to desire - liberty through the monarchy."

${ }^{30}$ For the historical reception of Maistre, see Armenteros and Lebrun (2011).
} 
The revolution also implicated two figures who, though not reactionaries themselves, shaped reaction that followed. The first was Jean-Jacques Rousseau, whose arguments inspired both the revolution itself and later forms of political anti-modernism. For Rousseau (1997:Note IX, 197), humanity was originally "naturally good," and human ills social creations, epitomized in $18^{\text {th }}$ Century Europe's corrupt, "bourgeois" society. Revolutionaries (both left and right) drew from this insight a radical programme: if all problems were social, then society itself could and should be transformed in order to perfect the human condition. In the reactionary version, this meant recreating a purer, more original society not yet corrupted by bourgeois culture. ${ }^{31}$ The second was Edmund Burke, whose Reflections on the Revolution in France founded modern conservatism. Like Maistre, Burke saw the Revolution as imposing a radically abstract, inhuman modernity on the tradition-dependent, complex reality of human life. ${ }^{32}$

In important respects, however, neither Rousseau nor Burke was reactionary. In very different ways, both were internal critics of the Enlightenment project. Burke represented a "progressive" conservative aspect of the Enlightenment, one that aimed to slow transformation and curtail universalism. ${ }^{33}$ Rousseau instead questioned the

\footnotetext{
${ }^{31}$ Rousseau did not describe, or necessarily intend, a program of political reaction. Indeed, many of his intellectual descendants were radicals of the left, Robespierre and Marx among them. For Rousseau and the French Revolution, see Furet (1997); for his practical politics, see Kelly's introduction to Rousseau (2005:xiii-xxiii).

${ }^{32}$ E.g. Burke (2014:17-36). Both excoriate modern theory or what Burke (e.g. 2014:8, 22, 59-62, 185-8, 224-7) labels "metaphysical" abstractions and Maistre (1994:41, 45, 47, 57) "philosophy" and "philosophism." But while Burke advocated armed intervention against the French Revolution, he also supported the progressive gradualism of British constitutionalism, defending the 1688 and 1776 revolutions (Welsh 1995). Maistre (1994:60-61, 104-121) disliked all three but was nonetheless a "liberal" or (we prefer) moderate reactionary: he admired Britain's constitutional monarchy, and although he wanted "a restoration of the old order... he ha[d] a fairly liberal understanding of what defined the old order" (Beiner 2011:350; cf. Garrard 2001:162-163). For Maistre's relationship with Burke, see Lebrun (2001).

${ }^{33}$ For example: "A state without the means of some change is a state without the means of its conservation"; "by preserving the method of nature in the conduct of the state, in what we improve we are never wholly new in what we retain we are never wholly obsolete" (Burke 2014:23, 35).
} 
Enlightenment's central transformative premises, before aiming to reform them in his later work. ${ }^{34}$

The modern project of political reaction is descended from these events and theorists, in more and less radical forms. The core ideas of reaction against the French Revolution - appeal to tradition and religion against revolutionary modernism - were expanded, modified, and transformed by later writers, influencing many of the statesmen responsible for the 1815 post-Napoleonic restoration, as well as a wave of subsequent reactionaries, including Louis de Bonald and Donoso Cortés. The French romantic writer Chateaubriand, for example, was a staunch royalist decades after the revolution, and a defender of Catholicism against secularizing Enlightenment critique. ${ }^{35}$ Later, Nietzsche's radical critique of western philosophy at times implied an extreme anti-modernismalthough never an expressed desire to revert to pre-modernity. ${ }^{36}$

The counter-revolutionary tradition extended into the twentieth century. In America, reaction came to refer to those who would, in William F. Buckley's (1955) phrase, "stand athwart history, yelling Stop"-in opposition to "Social Engineers" who would undermine "the organic moral order". Across the Atlantic, the influence of Maistre and Cortés was most visible in the decisionism of Carl Schmitt. In his international writings, Schmitt (e.g. 2003) evinced nostalgia for the pre-Wilsonian Jus Publicum Europaeum era of international public law, condemned the corroding effects of liberal 'Atlanticist' commercialism, and advocated supranational 'Großraüme' that could counter-balance Atlantist imperialism. ${ }^{37}$ Schmitt's antiliberalism has had wide impact:

\footnotetext{
${ }^{34}$ Although considered an Enlightenment thinker, Rousseau challenged prevailing narratives of scientific and social progress, arguing they had undermined political and social life. See Garrard (2003) and Pangle and Ahrensdorf (1999:185-190).

${ }^{35}$ Not all reactionaries of the period agreed unproblematically with one another in practice. Chateaubriand, for example, advocated unilateral French revision of the Vienna settlement status quo maintained by Metternich's congress system (Schroeder 1962:210, 229-236).

${ }^{36}$ Likewise, Spengler (1991) elaborated a nostalgic philosophy of history in which the West was in decline — but did not advocate any return to the past; see Dannhauser (1995).

${ }^{37}$ Despite his Nazism, Schmitt more closely resembled the moderate (if theocratic) reaction of Maistre (Garrard 2001; cf. Meier 2011). His core intellectual commitments did not advocate reversion to an antimodern social order, and thus were not wholly consistent with Nazism. In contrast, Heidegger (the other
} 
apart from his revival on the critical left, Schmitt has influenced Morgenthau's realism, writers on Europe's 'new right' such as Alain de Benoist (Hooker 2009:204-213), and the international thought of Russian Alexander Dugin. ${ }^{38}$ All these accounts partake to some degree in political reaction: they viewed reformatory social change itself as destructive, with some aiming to recreate a traditional social and political order in response.

In the twentieth century however, a second strain of reaction emerged, often linked to mass ideological movements. Influenced by Nietzsche and most distantly by Rousseau, writers such as Julius Evola lent it intellectual ammunition. This mass reactionary politics sought a more radicalized and uncompromising reversion to an original condition, or the revival of elements of a mythical past, since degraded by modernity, capitalism, or bourgeois society. It was most visible in National Socialism and other fascist movements, peaking in the 1930s and 1940s. Current reactionary European politics also bears this hallmark: far-right intellectual movements and parties on Europe's right - e.g. "Golden Dawn" - also seek to change the present to recover a stronger, purer past (Charalambous 2015). Such reactionary politics deploy modernizing means, including advanced communications and weapons technologies, and mass ideological movements, but do so to anti-modern ends, aiming to aggressively or radically transform the world around them. While defeated in WWII, this more radical or revisionist reactionary politics persists today. This is the case with many global jihadist movements, which combine reactionary politics with the techniques of modern politics. ${ }^{39}$

academic theorist most closely linked to Nazism) had vague but extreme political views. While thinly articulated, his reaction was likely more radical. Schmitt's international thought has attracted recent attention from IR scholars and others (Odysseos and Petito 2007; Hooker 2009).

${ }^{38}$ While Dugin's published works in English are mostly concerned with domestic politics, his account of international relations advocates an expressly reactionary formulation of Russia's place in the world (Astrov and Morozova 2012:209-215; Schouten 2014). His theory of multipolarity focuses on regionalcivilizational poles he claims can collectively counter U.S.-backed Atlanticist hegemony-an account indebted to Schmitt and classical geopolitics. Despite his public profile however, Dugin has found influence neither in mainstream western IR, nor in Russian foreign policy practice (Laruelle 2015). ${ }^{39}$ As Ahmad (2017:16-17) writes, a key aspect of today's "reactionary yet hypermodern" Islamist groups, such as ISIS and the Islamic Courts Union, lies in their promise to recreate "a romanticized golden age that 
Both moderate and radical political reaction accept certain premises of modern thought and politics, but do so in different, indeed opposed, ways. The first seeks to slow or pause modernity's progressive march by defending the traditional institutions modernity putatively undermines or attacks. The second radicalizes the modern premise that human society is malleable in an attempt to reconstruct or approximate a pre-modern society. It leverages modern ideologies and technologies to anti-modern ends. Nonetheless, the two lie on a continuum: actual instances may fall between them. The most radical extreme may take on the historical unreality of, for example, core Nazi ideology. Moderate reaction may shade into gradual acceptance of modernity itself.

\section{Reactionary World Politics}

If reaction has been an important feature of modern political thought, it has also been a recurring and often central feature of modern international political practice. To illustrate, we distinguish two ideal-type varieties of reactionary state action-revisionism and restructuring - and show briefly how each strategy plays out historically. The two correspond to the radical and moderate modes of reaction above.

Revision, the most direct approach, corresponds to the radical reactionary politics of militant anti-modernism. Faced with the perceived loss of a morally superior past, revisionist reactionaries set out to restore the status quo ante, often in direct and uncompromising ways. The diagnostic case is Nazi Germany. ${ }^{40}$ Believing in a premodern better world, and armed with the military capacity of a modern great power, Nazi elites set out to reconfigure European order by sheer force of arms, on the model of an imagined past.

predates the miseries of the colonial era and draws on an imagined conception of an Islamic nation that transcends all other loyalties." They also employ modern state-building techniques, co-opting and taxing local businesspeople, and use modern communications technology to recruit. A key early intellectual here is Qutb (2006), who whose anti-modernism is expressly reactionary - as distinct from progressive anticolonialisms. On parallels between Qutb and Maistre, see Euben (1999:199, n181).

${ }^{40}$ The Khmer Rouge are an alternate example, blending left and right, who sought to recreate the Khmer empire while "restoring" Cambodian society to a putative "year zero" by emptying urban centers, murdering the educated and foreign-influenced population, and instituting a closed agrarian society (Kiernan 2008). 
More moderate reactionaries may opt for a second approach: restructuring. Here, reactionaries aim to restore past political order through international coordination. Rather than directly recreate the past through force, restructuring aims to recreate past politics through institutions. Restructuring requires less coercion, emphasising instead multilateralism. Alliances multilaterally enforce a reactionary agenda, as new international institutional frameworks become the vessels for the restoration of past political, especially domestic, orders. ${ }^{41}$ The diagnostic case is the nineteenth century Concert of Europe, or "Metternich system" of counter-revolutionary management. Here, a coalition of European great powers restored and maintained the monarchical order that had preceded the French Revolution and Napoleonic Wars (Kissinger 2013). ${ }^{42}$ Below, these two historical examples illustrate the important but undiagnosed role reaction plays an in world politics. ${ }^{43}$

\section{Revisionism and the Third Reich, 1933-45}

The National-Socialist German state was perhaps the most extreme reactionary polity on record. While Nazi ideology could be vague and inconsistent (Mann 2004:14043), it aimed consistently "to restore to the German people an ethnic purity that was imagined to have existed in the past" (Turner 1972:551). That purity was thought to be embodied in the "First Reich" of Charlemagne — a loosely Germanic medieval empirewhich provided "a powerful symbolic link to the imagined greatness of the past" (Evans 2005:460), tied to the idea of a premodern Volk. This ancestral Germanic utopia had been echoed in Imperial Germany, from 1870 (the "Second Reich"), but it had been destroyed by the catastrophes that followed - defeat in WWI, a punitive peace, and Weimar-era economic disaster. Consistent with the view that "Fascists need a demonized enemy

\footnotetext{
${ }^{41}$ This "reactionary institutionalism" thus differs in goals, if not means, from the institutionalism of neoliberals (Keohane 1984) or neofunctionalists (Haas 1964). The contrast suggests there is little reason institutionalism is inherently liberal or progressive.

${ }^{42}$ Reactionary states with neither coercive capacity nor multilateral linkages may adopt a third strategy: withdrawal from the international community. Franco's Spain, for example, lacking both great power status and co-ideological states after 1945, isolated itself from the post-war international order.

${ }^{43}$ Concerned with theory building rather than testing, we select cases to illustrate, not to test specific explanations, emphasizing diagnostic cases, not ambiguous ones. The approach is akin to a "plausibility probe" (George and Bennett 2005:75).
} 
against which to mobilize followers" (Paxton 2007:37), the Nazis blamed the Jews for these circumstances. German Jews were less than one per cent of the interwar German population, and were largely assimilated. The Nazis nonetheless cast them as a inassimilable other-a stateless, landless, internationalized people, bound up with the vicissitudes of international finance putatively linked to German hardship (Snyder 2015:42-44).

The Nazis were not merely reactionary; they were revisionist. Their goals were wholly inconsistent with contemporaneous world order, and they had the coercive capacity to attempt reordering by force. ${ }^{44}$ With the military power of a rapidly rearmed Germany, they set out to expand their borders and remake Europe as an imagined premodern, racially stratified world: "they sought to transcend existing reality at one blow and substitute for it a radically different social order" (Turner 1972:552). So doing required leveraging modern technologies and institutional capacities to anti-modern ends. Nazi revisionism proceeded by war, structural reconfiguration, and genocide. ${ }^{45}$ Germany conquered, or subjected to unequal alliances, most European territories west of the rapidly receding Soviet frontier. The Nazis aimed to replace the European state system with a hierarchy, with themselves at its apex, by occupying, ethnically cleansing, and installing puppet regimes. They then set out to erase the Jews, whom they blamed for prewar Germany's ruin, from the face of the earth. ${ }^{46}$

Were German actions attributable to reactionary Nazi ideology? Even structuralist accounts of WWII suggest a linkage. Schweller (1998:5) allows that "Hitler's ideas distinguished him from prior German leaders", and that, while ideology did not cause the war, German reactionary revisionism, if not the specific content of Nazism, was an

\footnotetext{
${ }^{44}$ Reactionary revisionist states differ from other revisionists in their goals - the early Soviet Union aimed at world transformation, but was in no sense reactionary.

${ }^{45}$ The relationship between the Holocaust and modernity is contested. For Bauman (2001), the Holocaust is part of modernity itself, bound up with modern nationalism, technologically implemented mass murder, and the depersonalizing effects of modernity itself. We emphasize additionally the Nazis' expressed antimodernism. Herf (1986) terms Nazism a form of "reactionary modernism", a term since taken up by Mirowski (2013:212-17) to describe early IR theory.

${ }^{46}$ While the Nazis targeted and murdered multiple groups, they focused on Europe's Jews as those primarily responsible for putative German civilizational decline.
} 
important driver of war onset. While Nazism's ideological idiosyncrasies may not have been necessary, a will to overthrow the status quo and recreate a mythical past was. Restructuring and the Metternich System, 1815-1848

A prominent example of reactionary restructuring occurred during the great power management of post-Napoleonic Europe, sometimes labelled the "Congress system" or Concert of Europe ${ }^{47}$ Recent IR analyses have focused either on the Concert's progressive institutionalism or its material balance of power. Both understate the Concert's central repressive apparatus, sometimes called the "Metternich System," after Austrian foreign minister Prince Klemenz von Metternich. ${ }^{48}$ Although Metternich represented the weakest of Europe's five great powers, along with the Burkean Lord Castlereagh he played a central role in managing the post-Napoleonic restoration, such that Kissinger (2013:11) termed him "Prime Minister of Europe."

The Metternich system grew out of a series of treaties signed by Europe's powers, particularly the four - Prussia, Russia, Britain, and Austria - that contributed most to the defeat of Napoleon. Gathering in Vienna in 1814-15, the allies redrew the European map and restored many pre-Revolutionary monarchies, creating a territorial balance of power that hemmed in France and satisfied Europe's other powers (Jarrett 2013:43-205; Kissinger 2013:41-190). Worried that revolutions could spread throughout Europe and upset the Vienna settlement, Metternich spent the next three decades coordinating the allies - and after, 1818, France - in his efforts to repress Jacobinism, uphold monarchical legitimacy, and strengthen Great Power cooperation. Concerns about international stability and regime type were thus deeply intertwined: for Metternich, constitutionalist and liberal regimes threatened the hard-won Vienna equilibrium. ${ }^{49}$ Agreements at

\footnotetext{
${ }^{47}$ Labels for the post-Napoleonic order vary widely; see Schroeder (1962:4-5); Jarrett (2013:347-369). We sidestep this nomenclatural debate to focus on what has been labelled the "Metternich system": that component of the order committed to repressing constitutionalist rebellions, and which ended in 1848 . ${ }^{48}$ While realists downplay the role of ideas (Slantchev 2005), constructivists have acknowledged its illiberalism without focusing on it (Mitzen 2013). Earlier IR analyses sometimes feature the repressive apparatus (e.g. Morgenthau 1948:481-490); see also Vick (2014) for a criticism.

${ }^{49}$ Finnemore (1948:481-490). Like Maistre, Metternich respected British constitutionalism, but did not think it was transferable to the Continent. As the top minister in the multinational Austrian Empire, he had
} 
Troppau (1820) and Münchengrätz (1833) secured Prussian and Russian cooperation in Metternich's anti-revolutionary interventionist programme, which suppressed revolts in Italy and Poland. Aided by French disorganization and the Burkean tenor of British politics, Metternich was also largely successful in preventing the western cabinets from upsetting the Vienna restoration. As Alan Sked (2008:105) summarizes, "fear of revolution" was the "bottom line in international affairs" for Europe's powers, and "the real paradigm for European diplomacy between 1815 and 1848 was simply the Metternich system." In short, reactionary institution building was, for decades, the basis of European order. ${ }^{50}$

\section{Conclusion}

Reaction, we have argued, is absent from contemporary IR. However, it has a fragmentary presence in the field's history, is found extensively in the history of political thought, and has played a significant role in modern international political practice. This raises the question: why is there now no reactionary international theory? While space permits no detailed analysis, we suspect rejection of reactionary politics is linked to the field's putatively ameliorative orientation — that is, to its claimed roots in liberal idealism. The field's liberal identity implies a preconception of what is good in world politics - an assumed goal, to which reaction as such is anathema. ${ }^{51}$ Past IR reactionaries have thereby been rendered invisible. The historical linkages of IR's canonical schools to past reactionaries are thus forgotten. Early realists are read as emphasizing the permanent limits of political change. Early geopolitical reactionaries have, until recently, been read out of the discipline entirely. Liberal linkages to empire were elided as embarrassing. Later critical theorists rejected liberals and realists alike as un-reflexive and presentist, focused on the status quo. However, they did so in the name of "a critique of domination" that would explore means of resistance available to "those systematically or casually subjected to sustained forms of suffering, denigration, and/or exclusion" (Weber

\footnotetext{
a material interest in maintaining monarchical absolutism and suppressing nationalist revolt. See Sked (2008:esp. 1-25, 64-106, 244-246).

${ }^{50}$ See Jarrett (2013:esp. 72-84, 231-277), Schroeder (1962:235-266, 1994:583-804); and Sked (2008).

${ }^{51}$ When, for example, Angell (1972:59) insisted war "belongs to a stage of development out of which we have passed", he implied progress was both possible and desirable.
} 
2014:532). Such criticisms may reject reaction generally, but do little to distinguish it from the joint liberal-realist project of IR theory as such.

Why then does reaction matter? The practice of reactionary international politics appears now to be more widespread than at any time in the post-war period. At the time of writing, far right parties are active and perhaps ascendant across Europe, and appear to an extent to have been politically normalized. British voters, led by activists chiefly from the right, have narrowly chosen to leave the European Union, putatively restoring a more independent country. The stated positions of the new American president, who campaigned on a promise to "Make America Great Again," often upend the traditional party system and deride liberal international order (Patrick 2017). The so-called Islamic State has declared a Caliphate, modelled putatively on a premodern Islamic world order. Reactionary politics are on the march, and appear to be shaping the world political future. However concerning this may be, though, the account above reminds us these circumstances are not new: reaction is a recurring feature of international politics. ${ }^{52}$

If we are right, then the contemporary discipline, scrupulously forgetful of its reactionary past, is shorn of intellectual history that might clarify present circumstances. As now construed, IR is distinctively ill suited to address the rise of contemporary international reaction. In some respects, that rise might have been anticipated. A quarter century ago, in framing his otherwise ultra-liberal "end of history" thesis, Francis Fukuyama pointed to

a powerful nostalgia for the time when history existed. Such nostalgia, in fact, will continue to fuel competition and conflict even in the post-historical world for some time to come. Even though I recognize its inevitability, I have the most ambivalent feelings for the civilization that has been created in Europe since 1945, with its north Atlantic and Asian offshoots. Perhaps this very prospect of centuries of boredom at the end of history will serve to get history started once again. (Fukuyama 1989:18)

That nostalgia now appears present in force in world politics. In the years ahead, a central task for IR as a discipline will be to take reaction seriously, both as an intellectual tradition and as a form of political practice. Scholars whose political preferences are

\footnotetext{
${ }^{52}$ Outside the west, the Chinese philosopher Zhao Tingyang (2009) advocates reviving an idealized tianxia world order, modeled on the Zhou Dynasty, of more than two millennia ago.
} 
liberal or radical, or even focused on the realist status quo, may find little to dislike in their field's implicit anti-reactionary moral orientation. Our purpose is not to advocate a reactionary alternative, but instead to consider the analytical and political implications of having neglected reaction as such. A field that does not understand it in theory is ill equipped to understand and confront it in practice. (Meier 2011)

\section{Works Cited}

ACHARYA, AMitAV. (2014) Global International Relations (IR) and Regional Worlds. International Studies Quarterly 58: 647-659.

AHMAD, Aisha. (2017) Jihad \& Co.: Black Markets and Islamist Power. New York: Oxford University Press.

ANDERSOn, Brian C. (1997) Raymond Aron: The Recovery of the Political. Lanham, MD: Rowman \& Littlefield.

Angell, Norman. (1972) The Great Illusion, 1933. New York: Arno Press.

Armenteros, Carolina, and Richard Lebrun, Eds. (2011) Joseph de Maistre and His European Readers: From Friedrich von Gentz to Isaiah Berlin. Leiden: Brill.

Astrov, Alexander, and Natalia Morozova. (2012) Russia: Geopolitics from the Heartland. In The Return of Geopolitics in Europe?: Social Mechanisms and Foreign Policy Identity Crises, edited by Stefano Guzzini. Cambridge University Press.

BARKIN, J. SAMUEL. (2010) Realist Constructivism: Rethinking International Relations Theory. Cambridge: Cambridge University Press.

BAuman, Zygmunt. (2001) Modernity and the Holocaust. Ithaca, NY: Cornell University Press.

Bauman, Zygmunt. (2017) Retrotopia. Cambridge: Polity.

Beiner, Ronald. (2011) Civil Religion: A Dialogue in the History of Political Philosophy. New York: Cambridge University Press.

Bessner, Daniel, and Nicolas Guilhot. (2015) How Realism Waltzed Off: Liberalism and Decisionmaking in Kenneth Waltz's Neorealism. International Security 40: $87-118$.

Black, Jeremy. (2016) Geopolitics and the Quest for Dominance. Bloomington: Indiana University Press. 
Buckley, William F. (1955) Our Mission Statement. National Review. Available at: http://www.nationalreview.com/article/223549/our-mission-statement-william-fbuckley-jr. (Accessed December 5, 2016).

Bull, Hedley. (1959) What Is the Commonwealth? World Politics 11: 577-587.

BURKE, EDMUND. (2014) Revolutionary Writings: Reflections on the Revolution in France and the First Letter on a Regicide Peace. edited by Iain Hampsher-Monk. New York: Cambridge University Press.

BuZAn, BARRY. (2014) An Introduction to the English School of International Relations: The Societal Approach. Cambridge, UK: Polity Press.

BUZAN, BARRY. (2004) From International to World Society?: English School Theory and the Social Structure of Globalisation. Cambridge: Cambridge University Press.

Carr, EdWard Hallett. (2001) What Is History? Palgrave Macmillan Limited.

Ceadel, Martin. (2009) Living the Great Illusion: Sir Norman Angell, 1872-1967. Oxford.

Charalambous, Giorgos, Ed. (2015) The European Far Right: Historical and Contemporary Perspectives. Oslo: PRIO Cyprus Centre \& Friedrich-EbertStiftung.

Chiozza, Giacomo. (2002) Is There a Clash of Civilizations? Evidence from Patterns of International Conflict Involvement, 1946-97. Journal of Peace Research 39: 711734.

DAnnhauser, Werner J. (1995) Nietzsche and Spengler on Progress and Decline. In History and the Idea of Progress, edited by Arthur M. Melzer, Jerry Weinberger, and M. Richard Zinman. Ithaca: Cornell University Press.

Deudney, DANiEL. (2000) Geopolitics as Theory: Historical Security Materialism. European Journal of International Relations 6: 77-107.

Devall, Bill, and George Sessions. (1985) Deep Ecology: Living as If Nature Mattered. Salt Lake City, UT: Gibbs Smith.

Euben, Roxanne L. (1999) Enemy in the Mirror: Islamic Fundamentalism and the Limits of Modern Rationalism. Princeton, NJ: Princeton University Press.

Evans, Richard J. (2005) The Coming of the Third Reich. New York: Penguin.

FANON, FrAnTZ. (1965) The Wretched on the Earth. New York, NY: Grove Press. 
Finnemore, Martha. (2004) The Purpose of Intervention: Changing Beliefs about the Use of Force. Cornell University Press.

Fox, Jonathan. (2002) Ethnic Minorities and the Clash of Civilizations: A Quantitative Analysis of Huntington's Thesis. British Journal of Political Science 32: 415434.

Freedman, JoshuA. (2016) Status Insecurity and Temporality in World Politics. European Journal of International Relations 22: 797-822.

Friedman, Milton. (1962) Capitalism and Freedom. Chicago: University Of Chicago Press.

FunuYama, FRANCIS. (1989) The End of History? The National Interest. Available at: http://www.sendspace.com/file/awm4xu. (Accessed February 14, 2012).

Furet, FrAnÇOIS. (1997) Rousseau and the French Revolution. In Rousseau and the French Revolution, edited by Clifford Orwin and Nathan Tarcov. Chicago: University of Chicago Press.

Gaddis, John Lewis. (2011) George F. Kennan: An American Life. New York: Penguin Press.

Garrard, Graeme. (2001) Joseph de Maistre and Edmund Burke: A Comparison. In Joseph de Maistre's Life, Thought and Influence: Selected Studies, edited by Richard Lebrun. Montreal: McGill-Queen's University Press.

GARRARD, GRAEME. (2003) Rousseau's Counter-Enlightenment: A Republican Critique of the Philosophes. Albany, NY: State University of New York Press.

George, Alexander L., and Andrew Bennett. (2005) Case Studies and Theory Development in the Social Sciences. Cambridge, MA: MIT Press.

Gilpin, Robert. (1983) War and Change in World Politics. Cambridge: Cambridge University Press.

Gregory, Brad S. (2012) The Unintended Reformation: How a Religious Revolution Secularized Society. Cambridge, MA: Harvard University Press.

Guilhot, Nicolas, Ed. (2013) The Invention of International Relations Theory: Realism, the Rockefeller Foundation, and the 1954 Conference on Theory. New York: Columbia University Press.

HAAS, ERNST B. (1964) Beyond the Nation State: Functionalism and International Organization. Stanford, CA: Stanford University Press.

HaLl, IAN, Ed. (2015) Radicals and Reactionaries in Twentieth-Century International Thought. New York: Palgrave Macmillan. 
Hall, IAN. (2011) The Revolt against the West: Decolonisation and Its Repercussions in British International Thought, 1945-75. The International History Review 33: 4364.

Hall, Ian, and Nicholas Rengger. (2005) The Right That Failed? The Ambiguities of Conservative Thought and the Dilemmas of Conservative Practice in International Affairs. International Affairs 81: 69-82.

HASSNER, PIERRE. (1996) Morally Objectionable, Politically Dangerous. The National Interest: 63-69.

Henderson, Errol A. (2017) The Revolution Will Not Be Theorised: Du Bois, Locke, and the Howard School's Challenge to White Supremacist IR Theory. Millennium.

Herf, JefFrey. (1986) Reactionary Modernism: Technology, Culture, and Politics in Weimar and the Third Reich. Cambridge: Cambridge University Press.

Hobson, John M. (2012) The Eurocentric Conception of World Politics: Western International Theory, 1760-2010. Cambridge University Press.

HoOKer, WiLliam. (2009) Carl Schmitt's International Thought: Order and Orientation. New York: Cambridge University Press.

Huntington, Samuel P. (1997) The Clash of Civilizations and the Remaking of World Order. New York: Simon and Schuster.

Huntington, Samuel P. (2004) Who Are We?: The Challenges to America's National Identity. New York: Simon and Schuster.

JACKSON, PATRICK THADDEUS. (2011) The Conduct of Inquiry in International Relations: Philosophy of Science and Its Implications for the Study of World Politics. 1st ed. London: Routledge.

JARrett, MARK. (2013) The Congress of Vienna and Its Legacy: War and Great Power Diplomacy after Napoleon. London: I.B. Tauris.

KatA, AnNA. (2010) A Postmodern Pandora's Box: Anti-Vaccination Misinformation on the Internet. Vaccine; Kidlington 28: 1709-1716.

Katzenstein, Peter J., Ed. (2009) Civilizations in World Politics: Plural and Pluralist Perspectives. London: Routledge.

Kelly, Philip. (2016) Classical Geopolitics: A New Analytical Model. Stanford, California: Stanford University Press.

Kennan, George F. (2014) The Kennan Diaries. edited by Frank Costigliola. New York: W. W. Norton \& Company. 
Keohane, Robert O. (1984) After Hegemony: Cooperation and Discord in the World Political Economy. New Haven, CT: Princeton University Press.

Kiernan, Ben. (2008) The Pol Pot Regime: Race, Power, and Genocide in Cambodia Under the Khmer Rouge, 1975-79. Yale University Press.

Kissinger, HenRY. (1994) Diplomacy. New York: Simon \& Schuster.

Kissinger, HenRY. (2014) World Order. New York: Penguin Press.

Kissinger, Henry A. (2013) A World Restored: Metternich, Castlereagh and the Problems of Peace, 1812-22. Brattleboro, VT: Echo Point.

KuEHNELT-LEDDIHN, ERIK VON. (1952) Liberty or Equality; the Challenge of Our Time. London: Hollis \& Carter.

Laruelle, Marlene. (2015) Scared of Putin's Shadow. Foreign Affairs. Available at: https://www.foreignaffairs.com/articles/russian-federation/2015-03-25/scaredputins-shadow. (Accessed April 19, 2017).

LeVIne, DANIEL J. (2012) Recovering International Relations: The Promise of Sustainable Critique. New York: Oxford University Press.

LEVY, JACK S. (1987) Declining Power and the Preventive Motivation for War. World Politics 40: 82-107.

Lilla, Mark. (2016) The Shipwrecked Mind: On Political Reaction. New York: New York Review Books.

LitTLE, RichaRD. (2000) The English School's Contribution to the Study of International Relations. European Journal of International Relations 6: 395-422.

MacKay, Joseph, and Christopher David LaRoche. (2017) The Conduct of History in International Relations: Rethinking Philosophy of History in IR Theory. International Theory: 1-34.

Mackinder, Sir HALford John. (1919) Democratic Ideals and Reality: A Study in the Politics of Reconstruction. New York: Henry Holt and Company.

Maistre, JosePH DE. (1994) Considerations on France. edited by Richard Lebrun. New York: Cambridge University Press.

Maistre, Joseph De. (2006) Considérations sur la France. edited by Pierre Manent. Brussels: Editions Complexe.

Maliniak, Daniel, Susan Peterson, and Michael J. Tierney. (2012) 95 TRIP Around the World: Teaching, Research, and Policy Views of International Relations Faculty in 20 Countries. Williamsburg, VA: Teaching, Research, and 
International Policy (TRIP) Project, The Institute for the Theory and Practice of International Relations, College of William \& Mary. Available at: http://irtheoryandpractice.wm.edu/projects/trip/TRIPAroundTheWorld2011.pdf.

Mann, Michael. (2004) Fascists. Cambridge: Cambridge University Press.

Mearsheimer, John J. (2003) The Tragedy of Great Power Politics. W. W. Norton \& Company.

MeIER, HeInRICH. (2011) The Lesson of Carl Schmitt: Four Chapters on the Distinction between Political Theology and Political Philosophy. The University of Chicago Press.

MERCER, JONATHAN. (1995) Anarchy and Identity. International Organization 49: 229 252.

MiRowsKI, PhILIP. (2013) Realism Conservatism and Neoliberalism: From Reactionary Modernism to Postwar Conservatism. In The Invention of International Relations Theory: Realism, the Rockefeller Foundation, and the 1954 Conference on Theory, edited by Nicolas Guilhot. New York: Columbia University Press.

Mitzen, Jennifer. (2006) Ontological Security in World Politics: State Identity and the Security Dilemma. European Journal of International Relations 12: 341.

Mitzen, Jennifer. (2013) Power in Concert: The Nineteenth-Century Origins of Global Governance. Chicago: The University of Chicago Press.

Morgenthau, Hans J. (2004) Political Theory and International Affairs: Hans J. Morgenthau on Aristotle's The Politics. edited by Anthony F. Lang Jr. Greenwood Publishing Group.

Morgenthau, Hans J. (1948) Politics Among Nations: The Struggle for Power and Peace. New York: Knopf.

MÜller, JAN-Werner. (2016) What Is Populism? Philadelphia, PA: University of Pennsylvania Press.

Musgrave, Paul. (2017) The Grim Fantasia of a Civilizational War. Cato Unbound. Available at: https://www.cato-unbound.org/2017/02/08/paul-musgrave/grimfantasia-civilizational-war. (Accessed April 10, 2017).

Neacsu, Mihaela. (2010) Hans J. Morgenthau's Theory of International Relations: Disenchantment and Re-Enchantment. New York: Palgrave Macmillan.

Niebuhr, ReInHOLD. (2008) The Irony of American History. University of Chicago Press. 
Odysseos, Louiza, and Fabio Petito, Eds. (2007) The International Political Thought of Carl Schmitt: Terror, Liberal War and the Crisis of Global Order. Abingdon, Oxon: Routledge.

Pangle, Thomas L., and Peter J. Ahrensdorf. (1999) Justice among Nations: On the Moral Basis of Power and Peace. Lawrence, KS: University Press of Kansas.

Patrick, SteWART M. (2017) Trump and World Order. Foreign Affairs 96: 52-57.

Paxton, Robert O. (2007) The Anatomy of Fascism. New York: Knopf Doubleday.

QutB, SAYED. (2006) Milestones. New Delhi: Islamic Book Service.

RANDALl, AdRian J. (1986) The Philosophy of Luddism: The Case of the West of England Woolen Workers, Ca. 1790-1809. Technology and Culture 27: 1-17.

RoBIN, COREY. (2011) The Reactionary Mind: Conservatism from Edmund Burke to Sarah Palin. New York: Oxford University Press.

Roth, Michael S. (1991) Dying of the Past: Medical Studies of Nostalgia in NineteenthCentury France. History and Memory 3: 5-29.

Rousseau, Jean-JacQues. (1997) The Discourses and Other Political Writings. edited by Victor Gourevitch. New York: Cambridge University Press.

Rousseau, Jean-Jacques. (2005) The Plan for Perpetual Peace, On the Government of Poland, and Other Writings on History and Politics. edited by Christopher Kelly. Hanover, NH: Dartmouth College Press.

Scheuerman, William E. (2011) The Realist Case for Global Reform. Cambridge: Polity Press.

SCHMIDT, Brian, Ed. (2012) International Relations and the First Great Debate. London: Routledge.

SCHMIDT, BRIAN C. (2008) Political Science and the American Empire: A Disciplinary History of the "Politics" Section and the Discourse of Imperialism and Colonialism. International Politics 45: 675-687.

SCHMitT, CARL. (2003) The Nomos of the Earth in the International Law of the Jus Publicum Europaeum. edited by G. L. Ulmen. New York: Telos Press.

Schouten, PeEr. (2014) Theory Talk \#66: Alexander Dugin. Theory Talks. Available at: http://www.theory-talks.org/2014/12/theory-talk-66.html. (Accessed April 19, 2017).

Schroeder, Paul W. (1962) Metternich's Diplomacy at Its Zenith, 1820-1823. Austin: University of Texas Press. 
Schroeder, Paul W. (1994) The Transformation of European Politics, 1763-1848. Oxford: Clarendon: Oxford University Press.

SCHWEller, RANDAll L. (1998) Deadly Imbalances: Tripolarity and Hitler's Strategy of World Conquest. New York: Columbia University Press.

Schweller, Randall L. (2014) Maxwell's Demon and the Golden Apple. Baltimore, MD: Johns Hopkins University Press.

Seth, Sanjay. (2013) Postcolonial Theory and International Relations: A Critical Introduction. London: Routledge.

Sked, Alan. (2008) Metternich and Austria: An Evaluation. New York: Palgrave Macmillan.

SlantcheV, BRAnislav L. (2005) Territory and Commitment: The Concert of Europe as Self-Enforcing Equilibrium. Security Studies 14: 565-606.

Snyder, Timothy. (2015) Black Earth: The Holocaust as History and Warning. New York: Tim Duggan Books.

SPENGLer, Oswald. (1991) The Decline of the West. Oxford: Oxford University Press.

StefFeK, Jens. (2015) Fascist Internationalism. Millennium 44: 3-22.

Suzuki, Shogo. (2009) Civilization and Empire: China and Japan's Encounter with European International Society. London: Routledge.

Tuathail, GearóID Ó. (1996) Critical Geopolitics: The Politics of Writing Global Space. University of Minnesota Press.

Tuathail, Gearóid Ó, Simon Dalby, and Paul Routledge, Eds. (2006) The Geopolitics Reader. Second edition. New York: Routledge.

Turner, Henry Ashby. (1972) Fascism and Modernization. World Politics 24: 547564.

VICK, BRIAn E. (2014) The Congress of Vienna: Power and Politics after Napoleon. Cambridge, Massachusetts: Harvard University Press.

Vitalis, Robert. (2015) White World Order, Black Power Politics: The Birth of American International Relations. Ithaca, NY: Cornell University Press.

Waltz, Kenneth N. (1979) Theory of International Politics. New York: McGraw-Hill.

WeBer, MARTIN. (2014) Between "isses" and "oughts": IR Constructivism, Critical Theory, and the Challenge of Political Philosophy. European Journal of International Relations 20: 516-543. 
Welch, DAvid A. (2013) Enemy Wanted: Apply Without. E-International Relations. Available at: http://www.e-ir.info/2013/05/28/enemy-wanted-apply-without/. (Accessed January 20, 2017).

WeLSh, JENNIFER M. (1995) Edmund Burke and International Relations: The Commonwealth of Europe and the Crusade against the French Revolution. London: Macmillan Press.

Wight, MARTin. (1966) Why Is There No International Theory? In Diplomatic Investigations: Essays in the Theory of International Politics, edited by Herbert Butterfield and Martin Wight. Cambridge, MA: Harvard University Press.

Williams, Michael C. (2005a) The Realist Tradition and the Limits of International Relations. Cambridge: Cambridge University Press.

Williams, Michael C. (2005b) What Is the National Interest? The Neoconservative Challenge in IR Theory. European Journal of International Relations 11: 307337.

Woodside, AleXAnder. (2009) Lost Modernities: China, Vietnam, Korea, and the Hazards of World History. Cambridge, MA: Harvard University Press.

Zhao, Tingyang. (2009) A Political World Philosophy in Terms of All-under-Heaven (Tian-Xia). Diogenes 56: 5-18. 